\title{
The Scope and Limits of the Right to Sport in Turkish Law
}

\author{
Türk Hukukunda Spor Hakkının Kapsam ve Sınırları
}

\section{Taner Ayanoglu ${ }^{1}$ (}

\begin{abstract}
Today, sport has important functions which are not limited to human biology but also reflected in social, cultural, psychological, economic and many other activities. Sport activities, which are an indispensable activity in the life of individuals, must be accepted among the fundamental rights and freedoms protected by the legal order. The right to sport includes, on the one hand, the right and freedom of persons to exercise, and on the other hand, requests from the State to take measures to improve physical and mental health. Although this right is not explicitly regulated in the Constitution, the right to sport is considered to be a constitutional right and freedom, since the various rights and freedoms regulated and guaranteed by the Constitution include the right to sport. The right to sport, however, is not an unlimited right and freedom in either dimension. The right to sport may be restricted due to special restrictions in the Constitution.
\end{abstract}

\section{Keywords}

Human rights and freedoms, Right to sport, Public service, Social rights, Sports federations

Öz

Günümüzde spor, insanın biyolojisi ile sınırlı kalmayan, aynı zamanda sosyal, kültürel, psikolojik, ekonomik ve diğer birçok alandaki faaliyetlerine de yansıyan önemli işlevlere sahiptir. Kişilerin yaşamında vazgeçilmez bir etkinlik olan sportif faaliyetlerin, hukuk düzeni tarafından korunan temel hak ve özgürlükler arasında kabulü zorunlu olmaktadır. Spor hakkı, bir yandan kişilerin spor yapma hak ve özgürlüğüne sahip olmalarını, öte yandan da kişilerin Devletten beden ve ruh sağlığını geliştirecek tedbirleri almasına ilişkin talepte bulunmalarını içermektedir. Bu hak, Anayasa'da açıkça düzenlenmemiş olmakla, Anayasa düzenlenen ve güvence altına alınan çeşitli hak ve özgürlükler spor hakkını da içermekte olduğundan, spor hakkının anayasal bir hak ve özgürlük olduğu kabul edilir. Bununla birlikte, spor hakkı her iki boyutuyla da sınırsız bir hak ve özgürlük değildir. Anayasada yer alan özel sınırlama sebepleriyle spor hakkı sınırlanabilir.

\section{Anahtar Kelimeler \\ İnsan hak ve özgürlükleri, Spor hakkı, Kamu hizmeti, Sosyal haklar, Spor federasyonları}

\footnotetext{
1 Corresponding Author: Taner Ayanoglu (Assoc. Prof. Dr.), İstanbul Bilgi University, Law School, Department of Administrative Law, Istanbul, Turkey. E-mail: taner.ayanoglu@bilgi.edu.tr ORCID: 0000-0001-7768-2378

To cite this article: Ayanoglu T, "The Scope and Limits of the Right to Sport in Turkish Law" (2019) 68 Annales de la Faculté de Droit d'Istanbul 1. https://doi.org/10.26650/annales.2019.68.0001 


\section{The Scope and Limits of the Right to Sport in Turkish Law}

\section{Introduction}

In ancient times, for human beings, physical mobility was one of the most important talents of survival. In this way, mankind tried to eliminate the weaknesses against other living beings and gained power and sovereignty against nature. He later developed this by using tools such as bows and arrows, thereby gaining a relative advantage. In the early years of human history, sporting activities aimed at meeting the natural needs became a sociological phenomenon in itself by gaining a social dimension and training of the body in later times ${ }^{1}$.

Sports is an activity carried out for a wide variety of purposes. Individuals can engage in sports activities in order to be physically and mentally healthier, to spend their leisure time, to communicate with other individuals, or to compete or achieve competitive results ${ }^{2}$.

Today, sport has important functions which are not limited to human biology but also reflected in social, cultural, psychological, economic and many other activities. For this reason, it can be said that sport is an indispensable phenomenon that is interested in almost every aspect of human life. Whether sports, which have a multidimensional effect on people's lives, constitute a right and a freedom is an important field of study that needs to be addressed. In this article, we will briefly discuss the constitutional basis, scope and limits of the right to do sports in Turkish Law, and what are the duties assigned to the State in this regard.

\section{Basic Characteristics of Sportive Activities and Its Relationship with Human Rights and Freedoms}

Sports is a kind of activity that is unique to people. In living things, only people enjoy and enjoy some movements and activities. Camel wrestling, cockfighting, dog racing and horse racing do not indicate that animals are engaged in sports ${ }^{3}$. While some of the animals' behaviors are perceived as sports, no animal competes with the other because the movements of the animals are determined by instinct. Therefore, it is necessary to accept that only people do sports and animals do not do sports.

The need to act is a requirement of the human being's structure. Like all living things, human beings have needs, and as a Bio-Psycho-Social being, they make actions to meet their basic needs specific to these characteristics. Human beings are obliged to act

1 M Y Şahin and A F İmamoğlu, 'Akademisyenlerin ve Milletvekillerinin Spor Siyaset Etkileşimine Yönelik Görüşleri' (2011) GBESBD Vol. XVI, Iss. 2, 42.

2 Hatice Özdemir Kocasakal, Sportif Uyuşmazlıkların Tahkim Yoluyla Çözümü ve Spor Tahkim Mahkemesi (CAS) (Vedat 2013) 1.

3 Atilla Erdemli, 'Spor nedir?' in Kismet Erkiner (eds), Spor Hukuku Dersleri (Kadir Has University Press, 2007) 13. 
multidimensional. In this context, human beings, from work to nutrition, sexuality to daily activities in many activities to meet the specific needs of all the time. To see man as a body only is to see man as incomplete. Human is a Bio-Psycho-Social entity, and movement is functional in all areas of human life. Therefore, unlike animals, human beings can make multi-faceted and multi-purpose movements. On the one hand, one makes the movements necessary for his/her biological life, on the one hand performs different tasks according to his/her responsibilities and duties towards himself/herself and other people close to the distant, on the one hand, he/she enters into different behaviors for his/her own spiritual needs, take part in different activities for higher lives ${ }^{4}$.

There is also the phenomenon of physical movement at the basis of human activities defined as sports. Sports, above all, are the activities that people perform in the form of physical movements. As a matter of fact, according to Article 2.1.a of The European Sports Charter, "Sport means all forms of physical activity which, through casual or organised participation, aim at expressing or improving physical fitness and mental well-being, forming social relationships or obtaining results in competition at all levels" 5 .

However, although some of the bodily movements that people make to meet their various needs can be defined as sports activities, most of them are not considered as sports activities. It is not possible to define activities that people do not do sports for sports. For example, the work of a construction worker or taxi driver or the actions of a student's to go to school on foot or by bicycle is not considered as sporting activity. Because the purpose of such actions is not to do sports. Physical movements are defined as sporting activities only when they are carried out for the purpose of doing sports, which is, improving physical and mental health. Sometimes the activities that people do for sports may indirectly result in improving their physical and mental health. However, they cannot be considered as sports because they are not carried out for sports.

Sports is essentially an amateur action. The word amateur, comes from the root of "amare" in Latin, meaning love. Amateurism in sport refers to the fact that physical and physical activity constituting sport is loved because it is not done for another purpose, for example, for making money. However, in the adventure of sport in the 20th century, the fact that sporting activities were carried out with the aim of earning money emerged and thus professional sports emerged. In professional sport, sportive activity is carried out as a professional activity. In other words, a professional athlete has the status of "worker" who performs a certain sport as a profession. As a result, nowadays, the fact that sport is an amateur action in essence is not considered as an obstacle for the sport to be performed professionally ${ }^{6}$.

4 ibid $13,14$.

$5<$ https://rm.coe.int/16804c9dbb $>$ accessed 1 November 2019.

6 Erdemli, Spor nedir? (n 3) 19. 
It is unthinkable that sports activities of people do not constitute the subject of law. Therefore, two questions arise when sport meets law: "Do individuals have the right to make sports?" And "Is there such a thing as sports law?"7.

Whether it is in the form of physical and mental health, or in the form of acts of a profession, sportive activities are extremely important for the biological, psychological, sociological and economic existence and survival of people. For this reason, sporting activities should constitute a "right" for the people and be protected by the legal order. Nowadays, the legal relations created by sporting activities are mainly related to private law branches such as contract law, association law, corporate law, liability law, and may require the application of other law areas such as administrative law, tax law, criminal law and social insurance law ${ }^{8}$. Therefore, it is necessary to accept that people have the right to play sports, both in terms of their civil rights and as a person ${ }^{9}$.

Sport, which is an activity that will last throughout a person's life and an indispensable and inevitable necessity in his bio-psycho-social and cultural life, is also in direct and indirect interaction with other aspects of human life. Due to these characteristics, sport is at the same level as the right to life, the right to equality, the right to education and the right to self-development and is therefore a fundamental human right ${ }^{10}$.

There is also worth mentioning that various international documents contain various regulations on the right to sport, and there are directives in this documents for the right to be respected and respected by states ${ }^{11}$. The right to sport was first claimed by the Olympic movement as a human right. According to Article 4 of the Fundamental Principles of Olympism adopted by the International Olympic Committee (IOC), "The practice of sport is a human right. Every individual must have the possibility of practicing sport, without discrimination of any kind and in the Olympic spirit, which requires mutual understanding with a spirit of friendship, solidarity and fair play" " According to Article 24 of the Universal Declaration of Human Rights of 1948, "Everyone has the right to rest and leisure, including reasonable limitation of working hours and periodic holidays with pay"13. In addition, according to article 1.1 of International Charter of Physical Education, Physical Activity and Sport adopted by UNESCO in 1978, "Every human being has a fundamental right to physical

\footnotetext{
7 Necdet Azak, 'Spor Hukuku I' (1940), BTS, Iss. 24, 13.

8 Erdemli, Spor nedir? (n 3) 19.

9 Azak (n 7) 13.

10 Atilla Erdemli, 'Temel İnsan Hakları ve Spor”, Spor Hukuku Dersleri' in Kısmet Erkiner (eds), Spor Hukuku Dersleri (Kadir Has University Press, 2007) 30.

11 Şahin and İmamoğlu (n 1) 37.

$12<$ http://www.olimpiyatkomitesi.org.tr/Upload/Menu/624923_ioc_antlasmasi.pdf> accessed 1 November 2019.

$13<$ https://www.un.org/en/universal-declaration-human-rights/>accessed 1 November 2019
} 
education, physical activity and sport without discrimination on the basis of ethnicity, gender, sexual orientation, language, religion, political or other opinion, national or social origin, property or any other basis" 14 .

It is inconceivable that individuals' activities related to sport and the right to sport are not interested in the fundamental rights and freedoms stipulated in the Constitution. According to Article 12 of the Constitution, "Everyone has the fundamental rights and freedoms which are bound to his personality, untouchable, transferable and indispensable" and at this point, it is necessary to determine the relationship between the individuals' right of sport and the fundamental rights and freedoms guaranteed in the Constitution. This is because the 1ssue that individuals make requests for sporting activities or protection from interventions against sporting activities depends, first of all, on whether the sporting activities constitute a constitutional right, and what the nature and limits of the right are.

\section{Constitutional Regulations Regarding Sports Right}

Is sports a constitutional fundamental right and freedom? If so what kind of fundamental right and freedom is it? The answer to these questions should be sought in the Constitution.

The right to sport is not directly and explicitly regulated in the Constitution. Sportive activities are multidimensional phenomena and because of these dimensions they are interested in many fundamental rights and freedoms. Therefore, many rights and freedoms in the Constitution have a direct or indirect connection to the right to sport.

When sporting activities are carried out by individuals for the purpose of earning profits, they are practiced as a profession and become professional sport. Within the freedom of work and contract, there is also the freedom to exercise sport as a profession ${ }^{15}$. Therefore, in the case of sport as a profession, the right to do sport is covered by the right to work ${ }^{16}$.

Considering the necessity of learning in order to do a certain sport, there is again the right to education ${ }^{17}$. The right to education and training includes also freedom to learn and teach sports ${ }^{18}$.

$14<$ www.unesco.org/new/en/social-and-human-sciences/themes/physical-education-and-sport/sport-charter/> accessed 1 November 2019.

15 Seref Ertaş and Hasan Petek, Spor Hukuku (3th edn, Yetkin 2017) 57; Ramazan Çağlayan, Spor Hukuku, (Asil 2007 ) 24.

16 Constitution, Article 48: "Everyone has the freedom to work and conclude contracts in the field of his/her choice. Establishment of private enterprises is free. ..."

17 Constitution, Article 42: "No one shall be deprived of the right of learning and education. The scope of the right to education shall be defined and regulated by law. ..."

18 Ertaş and Petek (n 15) 56; Çağlayan (n 15) 24. 
Considering the positive contribution and benefits of sports activities to the physical and mental health of individuals, it is seen that they are interested in the right to benefit from health services and to live in a healthy and balanced environment. Considering the positive contribution and benefits of sports activities to the physical and mental health of individuals, it is seen that they are interested in the right to benefit from health services and to live in a healthy and balanced environment ${ }^{19}$. Article 56/3 of the Constitution imposes a duty on the State to ensure that everyone lives and lives in physical and mental health. As a matter of fact, it is stated in the reasoning of the Advisory Council regarding the article 59 of the 1982 Constitution that the protection of body health by having sports is a part of the health services ${ }^{20}$.

In addition, within the framework of the positive contributions and benefits of sports activities to the physical and mental health of individuals; Article 59 of the Constitution imposes also the duty on the State to take measures to develop the physical and mental health of Turkish citizens of all ages and to encourage the spread of sports among the masses ${ }^{21}$.

Article 59 of the Constitution does not define the right to exercise and participate in sports activities as a fundamental right and freedom. Article 59 imposes on the state only as a social duty to creating opportunities for citizens to improve their physical and mental health. Therefore, starting from Article 59 of the Constitution, it is not possible to say that the right to do sports is a fundamental right and freedom that is directly recognized in the Constitution ${ }^{22}$. The social rights dimension of the right to sport can be derived from the articles 56 and 59 of the Constitution. However, it is not easy to conclude from these articles that individuals have the right and freedom to engage in sports activities for sports activities not covered by the rights to work and education.

It appears that the regulations in the Constitution concern the right to sport, either because the elements of sport are the subject of other rights and freedoms, or because the duty of the State to make positive actions on sporting activities. Therefore, although it is not possible to derive the right to sport from these regulations, it is not possible to say also that the right to sport is not included in the Constitution in any way.

Necdet AZAK defines the "right to sport" in 1940 as "the right to make a sport that people like, in accordance with the rules that have been given in the country for

19 Constitution, Article 56: "Everyone has the right to live in a healthy, balanced environment. (...) To ensure that everyone leads their lives in conditions of physical and mental health and to secure cooperation in terms of human and material resources through economy and increased productivity, the state shall regulate central planning and functioning of the health services. (...)"

$20<$ https://acikerisim.tbmm.gov.tr/xmlui/bitstream/handle/11543/1169/200901027.pdf> accessed 1 November 2019.

21 Constitution, Article 59: "The state shall take measures to develop the physical and mental health of Turkish citizens of all ages, and encourage the spread of sports among the masses. ..."

22 Ertaş and Petek (n 15) 57; Çağlayan (n 15) 24. 
this kind of sport" ${ }^{\prime 23}$. However, when we talk about the right to sport in general today, on the one hand, it is understood that people can exercise their sports activities freely and that these activities should not be interfered with or prevented; on the other hand, a social right is understood which includes the demand of individuals from the State to provide various facilities and facilities for sportsmen, and to provide the necessary facilities such as facilities, fields, halls, tools and equipment for the realization of sport.

There is no doubt that the right to sport is regulated in article 59 of the Constitution with the social right dimension. However, it is also possible to infer from the regulation of Article 59 of the Constitution that the right to sport takes place with the dimension of freedom. Indeed, the concept of improving physical and mental health in Article 59 corresponds to the definition of sport. If sport is defined as a part of one's right to develop himself / herself physically and spiritually; by interpreting Articles 59 and 17 of the Constitution together, it can be concluded that the right to protect and improve the material and spiritual existence of individual includes the right to exercise sports ${ }^{24}$.

It appears that the right and freedom to play sports, although regulated directly in the Constitution, is actually indirectly included in the Constitution. According to article $17 / 1$ of the Constitution, "Everyone has the right to life and the right to protect and develop his material and spiritual existence."

The general purpose of the right to doing sport is to protect and improve one's body and intellectual abilities ${ }^{25}$. The fundamental right to the protection of a person's material and spiritual existence in article 17 of the Constitution includes, although not explicitly stated, also the right to do sports. In other words, doing sports is a part of one's freedom to develop oneself physically and mentally ${ }^{26}$.

The right of people to develop their material and spiritual existence includes the right to perform cultural, artistic, scientific and similar human activities as well as the right to doing sports. Therefore, the right of people to live, to protect and develop their material and spiritual existence includes their right to improve their physical and mental health. The concept of improving physical and mental health corresponds to the definition of sport in accordance with article 59 of the Constitution.

On the other hand, the article 59 of the Constitution giving the State the duty to take measures to improve the physical and mental health of individuals, it clearly shows that the Constitution-maker attaches great importance to the improvement of

23 Azak (n 7) 13.

24 Ertaş and Petek (n 15) 56; Çağlayan (n 15) 24.

25 Çağlayan (n 15) 24.

26 Ertaş and Petek (n 15) 56. 
physical and mental health of individuals. Indeed, the Constitution-maker assumes the public interest in this duty. Accordingly, it would be contrary to the Constitution the State's carrying out practices contrary to the purpose of improving the physical and mental health of individuals. This shows that in according to article 59 of the Constitution people have the right to improve their physical and mental health that is the right to do sport. Therefore, even if right of individuals to do sport is not explicitly recognized in Article 59 of the Constitution, it is implicitly recognized ${ }^{27}$.

To sum up, the right to sport is enshrined in the Constitution both as the freedom of individuals to exercise and as a social right that they can direct to the State. Therefore, it can be said that the right to sport is a two-character right and freedom. According to Jellinek's conceptualization, the right to sport has the characteristics of both negative status and positive status rights. The right to exercise sport freely which exists within the right to sport is a negative status right and we can call it the freedom to do sports. On the other hand, the right of individuals to request positive actions from the State in order to carry out sporting activities which exists within the right to sports is the right to positive status and we can call it a sporting social right.

\section{The Scope and Limits of Sports Right}

\section{A. The Scope and Limits of the Freedom to Do Sports}

Within the scope of the right to sport, people are free to exercise in order to improve their physical and mental health or as a profession. Accordingly, the restriction and prohibition of individuals from doing certain sports is incompatible with freedom in this field. Similarly, it is also incompatible with this freedom for people to be forced to do certain sports by public power or otherwise.

At this point, the question of whether the freedom of individuals to exercise is an absolute right or whether it is possible to restrict or prohibit it in certain situations should be answered.

It means that the restriction or prohibition of the freedom of persons is prohibited to do certain sports or all sports.

At this point, first of all, it is necessary to examine whether a law prohibiting sports is in conformity with the Constitution. "Can sports be prohibited?" This question, at first sight, may seem meaningless because of the irrationality of such a ban. But the history of mankind is full of bad examples of irrational prohibition practices.

This question should be addressed not in the context of the prohibition of sport in general, but in the context of the prohibition of certain types of sport because of their 27 Ertaş and Petek (n 15) 54. 
conflict with established cultural, social, religious and political values. Therefore, this question should not be considered in the context of the prohibition of sports in general. Some types of sports are banned because of their conflict with established cultural, social, religious and political values. Likewise, the right to sport is prohibited in some cases because of its conflict with other rights and freedoms. For example, table tennis was banned in the Soviet Union between 1930 and 1950 on the grounds that it disrupted the eye health of the audience. Nowadays, there are also opinions that sports like life-threatening wingsuit, boxing or cage fighting should be banned.

It should be noted article 59 of the Constitution provides the State with the task of developing and promoting sports. For this reason, a law prohibiting sports will be contrary to the Constitution as it will make it difficult and eliminate the State to fulfill its duty. Because of that article 59 of the Constitution gives the State the duty to take measures to improve the physical and mental health of individuals, the Constitution recognizes that sport is for the public interest. Accordingly, doing sports is a right guaranteed by the Constitution and as a rule cannot be abolished by the State ${ }^{28}$. The right to engage in sportive activities is also part of the right to develop its material and moral existence, which is regulated in Article 17 of the Constitution. In this respect, legal regulations and administrative procedures that force people to do sports or prohibit people from doing sports cannot be made ${ }^{29}$.

However, no fundamental rights and freedoms are unlimited and the right to sport is not also unlimited. in the Constitution the principles of limiting fundamental rights and freedoms in articles 13, 14 and 15 of, the reasons for the limitation in article 17 which regulate the right to develop material and spiritual existence, reasons of limitation in article 42 regulate the right to education and training, the reasons for the limitations in article 48 regulate the freedom to work and conclude contracts, are also valid for the right to sport $^{30}$.

The right to improve physical and mental health can be limited to the reasons for the restriction in this article, as it is based on the right to protect and promote the material and spiritual existence of individuals in Article 17 of the Constitution. The reasons for the restriction in Article 17 are more concerned with the right to life and the protection of body integrity. This article does not foresee any reason for the limitation of the right to protect and develop its material and moral existence. However, it can be said that the reason for the limitation of the right of individuals to protect and develop their material and moral existence is within this right itself. The right of people to protect their material and spiritual assets includes also the right to life and the inviolability of body integrity. In addition, Article 56/3 of the

28 Ertaş and Petek (n 15) 53, 55.

29 Çağlayan (15) 24; Ertaş and Petek (n 15) 57.

30 Çağlayan (n15) 25. 
Constitution imposes a duty on the State to ensure that everyone lives and lives in physical and mental health. The life of people and the integrity of the body is also protected against the people themselves. For this reason, the right of people to improve their physical and mental health within the scope of their right to protect their physical and spiritual existences also necessitates protection of their right to life and physical integrity against to sporting activities that will harm their physical and spiritual existences.

In this context, a provision that prohibits sports is contrary to the Constitution to the extent that it is contrary to the right to develop the physical and spiritual existences in which it is included. However, it is possible to prohibit any sporting action that involves serious dangers to the right to life of athletes, spectators or other persons, is in conflict with other superior rights and freedoms and is therefore deemed to disrupt public order.

As it is known, although the right to sport is a constitutional right and freedom, in some cases it may be in conflict with other rights and freedoms. For example, the conflict between the continuity of natural life and sports activities such as safari, hunting, fishing; conflict between boxing and body integrity; conflict of motor racing and environmental (noise) right; such as conflict of freedom to travel with marathon or bike races. As mentioned above, the conflict between the right to sport and other rights and freedoms is resolved according to which rights and freedoms are held superior. In case of conflict, in some cases the right to sport, in other cases other rights and freedoms may be held superior or in some cases a balance between conflicting rights and freedoms may be set. For example, if the roads are closed for a certain period of time due to bicycle races the right to sports is superior to the freedom of travel, in the case of the prohibition of hunting for certain animals the continuity of natural life is superior to the right to sport ${ }^{31}$.

Indeed, The European Court of Human Rights (ECtHR), decided that the prohibition on tradition of landowner's hunting wild mammals on their land with dogs was not contrary to private life, family life and immunity to housing ${ }^{32}$. In the case of Herrmann v. Germany, The Court decided that obligation to allow a landowner to hunt on his land violated his right to property ${ }^{33}$. In these cases, the ECtHR held the continuity of natural life and the right to property superior to the right to sport.

31 For example, in Turkey the Bolu Branch of Forestry and Water Affairs within the scope of hunting tourism tenders for hunting red deer. However, there is a public reaction to this practice. $<\mathrm{http}: / / \mathrm{www}$.bolutakip.com/haber/paran-varsa-geyikvurabilirsin> accessed 1 November 2019, <https://www.haberturk.com/bolu-haberleri/72449785-9-bin-tlye-kizil-geyikavi $>$ accessed 1 November 2019.

32 Friend and Others $v$ the United Kingdom (dec.) - 16072/06 and 27809/08, Decision 24.11.2009 [Section IV], <http:// hudoc.echr.coe.int/eng?i=002-1236> accessed 1 November 2019.

33 Herrmann $v$ Germany, 26 June 2012 (Grand Chamber), (Application no. 9300/07), <http://hudoc.echr.coe.int/ eng? $\mathrm{i}=001-111690>$ accessed 1 November 2019. 
The other dimension of the freedom to do sports is that people do sports subject to their own will, and they cannot be forced to do sports. In other words, the obligation of doing sports is incompatible with the freedom of sports. More specifically, the freedom to do sports also includes the right and freedom to non-sports, i.e. the right to laziness. According to article 4 of the Law on Physical Education in Turkey, dated June 29, 1938, "It is compulsory for young people to enter clubs and continue physical training in their free time." Certainly, with this legal regulation, the obligation to engage in sports contrary to the freedom to do sports was introduced. In 1964, the Constitutional Court ruled that this legal regulation which violated the principle of freedom was contrary to the Constitution and its cancellation which grounds that " $i t$ is necessary not to hold the individuals' activities of physical training and sports, which are a subject of education and training on the non-compulsory, and leave it to their own will"34.

Today, most of the sporting activities are not done to improve physical and mental health, but as a professional activity and to make money. The constitutional basis of the right to exercise sport as a profession is not the article 17 of the Constitution regarding the right to protect and improve the material and spiritual existence of the individuals, is article 48 of the Constitution regarding the right to freedom of work and contract. Although freedom of work and contract is included in the social and economic rights section of the Constitution, it is by nature a negative status right. Therefore, within the framework of the right to professional sports based on freedom of work and contract, the State does not have to act positively, but on the contrary, the State should not impose restrictions and prohibitions.

In the case doing of sport as a profession, sporting activities are, as a rule, subject to the restriction regime of the freedom of work and contract. However, the right to professional sport, which is based on the freedom of work and contract, is also subject to the same restriction and prohibition regime as sporting activities aimed at improving physical and mental health. Therefore, professional sporting activities, which may seriously compromise the rights of life of athletes, spectators or other persons, conflict with other superior rights and freedoms and disrupt public order, may also be prohibited. At this point, it is necessary to distinguish between the concept of prohibiting certain sporting actions due to public order and the concepts of temporary or permanent prohibition of the actions of athletes who conduct sport as a professional activity. The prohibition of professional athletes from doing sports on a temporary and permanent basis is essentially a limitation of the freedom to work and contract. On the other hand, it is not possible to say that athletes who have signed professional contracts have the right not to work, that is to say, not to

34 CC, 03.11.1964, 152/66, R.G.17.3.1965-11955, <http://kararlaryeni.anayasa.gov.tr/Karar/Content/4fdfe 721-894b-4a028ac5-5ef1e58c69a8? excludeGerekce=False\&wordsOnly=False $>$ accessed 1 November 2019. 
do sports. Professional athletes are obliged to fulfill their contractual performance during the contract.

The principles regarding the limitation of sports activities carried out in order to improve physical and mental health or as a professional activity are as above. At this point, it should be noted that in some cases, athletes or clubs are deprived of the opportunity to engage in sports, if they were not admitted to competitions for various reasons, such as punishment or not being able to achieve the necessary success. Such situations often arise as a result of the monopolistic power of organizations that organize competitive sports. In general, decisions and practices of non-admission to competitions and sporting organizations due to freedom of contract are not considered as a restriction of the right to do sports. Because, in such cases, it is not prohibited for the athlete or sports club to engage in that sport. However, if the organizations organizing a particular sport are monopoly or dominant position owners, and the equality of opportunity is not provided to the athletes or sports clubs willing to participate, then they must benefit from the legal protection of their right to participate in competitions and organizations ${ }^{35}$.

\section{B. Scope and Limits of Social Sport Right}

According to article 59/1 titled "Development and arbitration of sport" in the Third Section of the Constitution entitled "Social and Economic Rights and Duties", "The State shall take measures to develop the physical and mental health encourage the spread of sports among the masses." Article 59 of the Constitution imposes an obligation on the State for the development of sports and, sport is seen as a tool that improves physical and mental health ${ }^{36}$. In short, according to this article, people have a social right.

The duty of taking measures to improve the physical and mental health of the persons who are imposed on the State by the Constitution is a different duty from not impeding or prohibiting the sports activities of the individuals. Article 59 of the Constitution provides the State with two interrelated tasks: "taking measures" and "encouraging". Although the concept of taking measures is a very general task definition, since this article gives people a social right, it is clear that the State is given the task of making a positive action on the activities that improve the physical and mental health of individuals. The state can take a variety of "measures" such as to vide education and training support according to sports branches in order to develop and promote the

35 In a lawsuit filed in US courts against this decision of the United States National Olympic Committee (USOC), which refused to participate in the Olympic Games due to the Soviet occupation of Afghanistan in 1980, the US National Olympic Committee rather than being an organ, it is recognized as a local representative of the IOC and the right of athletes to participate in the Olympics is not protected. K Gürten and S E Erenel, 'Lex Sportiva: Spor Hukukunun Küreselliği' (2012) IUHFD, Vol.3, Iss.1, 308.

36 Nuray Ekşi, Spor Tahkim Hukuku (Beta 2015) 17. 
spread of sports to the masses, to provide sports equipment, to construct and use all kinds of sports facilities and halls, to organize sports competitions and competitions to grant scholarships or awards to successful athletes to establish sports organizations.

In article 59 of the Constitution, sport is defined as one of the services of the state regulated by the Constitution ${ }^{37}$. Since the sport has an interest with public health aspect, there is also possible for the State to on sports activities as a public service ${ }^{38}$. The duty to take these measures, each of which is a social right for individuals, constitutes a public service for the State.

The fact that the duty of the State to take measures to improve sporting activities and to promote the spread of sports to the masses is a public service, undoubtedly allows the State to establish administrative organizations to carry out these public services and to carry out its duties. Therefore, within the framework of Article 59 of the Constitution, the State may fulfill this duty by establishing administrative organizations such as ministries and general directorates for carrying out, managing and regulating sporting activities or by establishing sports federation for organizing and conducting sporting organizations ${ }^{39}$.

Although the 1982 Constitution imposes duty to the State to exercise the necessary measures for the physical and mental health of citizens, to promote the popularization of sports and to protect successful athletes, but does not foresee it to govern the sport in the form of a monopoly. However, the Constitution does not prevent the State from choosing a monopolistic structure.

Article 65 of the Constitution titled "limits of the economic and social duties of the State" stipulates that the State shall fulfill its duties to develop and promote sports, which can be defined as a sportive social public service, "within the scope of the adequacy of its financial resources". As stated in Article 65 of the Constitution, the State will try to fulfill this duty within the scope of its economic means ${ }^{40}$. Thus, a limit has been drawn to the social claims of individuals regarding sports with the Constitution.

\section{Conclusion}

The phenomenon of sports born as an amateur human activity has gained an industrial dimension today. Sports law includes the right and freedom to work as an industrial activity. Lex sportiva which dominate sports law unfortunately did not pay

37 B Öztan and M R Will, ‘Türkiye'de Müstakbel Spor Hukuku' (2010) Prof. Dr. Firat Öztan’a Armağan, Vol.II, 1759.

38 Çağlayan (n 15) 17.

39 The Constitutional Court has decided that the sports federations established for the purpose of organizing sports activities more efficiently and expeditiously and providing sports activities to the wider masses are decentralized administration institutions. See Cons. Court, 16.01.2015, 77/4, <http://kararlaryeni.anayasa.gov.tr/Karar/Content/eaa479b4-e71a-46079681-3b4e066a54c4? excludeGerekce=False\&wordsOnly=False > accessed 1 November 2019. 
enough attention to the right to sports. However, it should not be forgotten that there is a wider field of sports law including individual sports activities that are not covered by lex sportiva.

As a final word, the right of sport should be at the center of the sport law of individuals, because the starting point of sport law is the "right to sport". Throughout history, as an act that exists in every age in which human beings exist, sport will emerge as a basic human right in the 21 st century more functional and more important than today ${ }^{41}$.

Grant Support: The author received no grant support for this work.

\section{List of Abbreviations}

$\begin{array}{ll}\text { BTS } & \text { : Beden Terbiyesi ve Spor } \\ \text { CC } & \text { : The Constitutional Court } \\ \text { ECtHR } & : \text { The European Court of Human Rights } \\ \text { GBESD } & \text { Gazi Beden Eğitimi ve Spor Bilimleri Dergisi } \\ \text { IOC } & : \text { The International Olympic Committee } \\ \text { IUHFD } & : \text { İnönü Üniversitesi Hukuk Fakültesi Dergisi } \\ \text { Iss } & \text { : Issue } \\ \text { p } & \text { : page } \\ \text { v } & \text { : Versus } \\ \text { Vol } & : \text { Volume }\end{array}$

\section{Bibliography}

Azak N, 'Spor Hukuku I’ (1940), BTS, Iss. 24.

Çağlayan R, Spor Hukuku, (Asil 2007) 24.

Ekşi N, Spor Tahkim Hukuku (Beta 2015).

Erdemli A, 'Spor nedir?' in Kismet Erkiner (eds), Spor Hukuku Dersleri (Kadir Has University Press, 2007).

Erdemli A, 'Temel İnsan Hakları ve Spor”, Spor Hukuku Dersleri' in K1smet Erkiner (eds), Spor Hukuku Dersleri (Kadir Has University Press, 2007).

Ertaş Ş, Petek H, Spor Hukuku (3th edn, Yetkin 2017) 57.

Gürten K, Erenel SE, 'Lex Sportiva: Spor Hukukunun Küreselliği’ (2012) IUHFD, Vol.3, Iss.1.

Öztan B, Will MR, ‘Türkiye'de Müstakbel Spor Hukuku' (2010) Prof. Dr. Fırat Öztan’a Armağan, Vol.II.

Özdemir-Kocasakal H, Sportif Uyuşmazlıkların Tahkim Yoluyla Çözümü ve Spor Tahkim Mahkemesi (CAS) (Vedat 2013).

Şahin MY, İmamoğlu AF, 'Akademisyenlerin ve Milletvekillerinin Spor Siyaset Etkileşimine Yönelik Görüşleri’ (2011) GBESBD Vol. XVI, Iss. 2.

41 Erdemli, Temel İnsan Hakları ve Spor (n10) 30. 